ljtihad: Jurnal Wacana Hukum Islam dan Kemanusiaan

Vol. 21, No. 1 (2021), pp. 59-78, doi : 10.18326/ijtihad.v2111.59-78

\title{
Operational permits and brandings of savings and loan cooperatives and sharia financing (KSPPS) in legal validity perspective
}

\author{
Anjar Kususiyanah, Soleh Hasan Wahid, Wahyu Saputra \\ Institut Agama Islam Negeri (LAIN) Ponorogo \\ E-mail:kususiyanahanjar@gmail.com,solehbasan80@gmail.com,wahyn@iainponorogo.ac.id \\ DOI: 10.18326/ijtihad.v21i1.59-78
}

\begin{abstract}
This article described the legal validity of Savings and Loan Cooperatives and Sharia Financing (KSPPS) in East Java Region, especially regarding operational permits and their brandings. Most of them have KSPPS operational permits but in their operations use Baitul Mall Wa Tamwil (BMT) brand. Meanwhile, based on Chapter 2 Article 2 Point 7 of the Regulation the Minister of Cooperatives and Small and Medium Enterprises (SMEs) Number: 11/PER/M.KUKM/XII/2017, it is mandatory for every cooperative branch office and service network to display the cooperative identity either the name or logo, and not the BMT brand. The problem in this study was discussed using legal validity theory from philosophical, juridical and sociologicaldimensions. This was a qualitative research with a sociological, juridical, philosophical approach. Data collection techniques were divided into two, namely literature study to explore legal documents as data to review philosophical and juridical aspects and field studies to explore information from KSSPS in East Java to analyze the sociological aspects of the validity of the Regulation. The findings of the research were: the legal validity of the Ministerial Regulation Number: 11/PER/M.KUKM/XII/2017 from a philosophical point of view is not in line with the legal ideals of cooperatives in Indonesia. While from a juridical side, there is a legal vacuum. In addition, from a sociological dimension, it has not run perfectly due to non-optimal socialization from policy makers.
\end{abstract}

Artikel ini memaparkan tentang keberlakuan hukum Koperasi Simpan Pinjam Pembiayaan Syariah (KSPPS) yang berada di lingkungan Jawa timur, khususnya tentang ijin operasional dan penggunaan branding lembaga keuangan. Mayoritas KSPPS yang berada di jawa timur memiliki ijin operasional KSPPS akan tetapi dalam operasionalnya menggunakan brand "baitul mall watamwil (BMT)". 
Seharusnya berdasarkan ketentuan dalam bab 2 pasal 2 point 7 Peraturan Menteri Nomor 11 tahun 2017 dalam setiap kantor cabang dan jaringan layanan koperasi wajib memasang identitas koperasi baik nama ataupun logo gerakan koperasi dan bukan brand BMT. Masalah dalam kajian ini dikupas menggunakan teori keberlakuan hukum yang memiliki 3 dimensi yakni keberlakuan filosofis, keberlakuan yuridis dan keberlakuan sosiologis. Penelitian ini merupakan riset kualitatif dengan pendekatan sosiologis, yuridis, filosofis. Teknik pengumpulan data terbagi menjadi dua yakni studi pustaka untuk menggali dokumen hukum sebagai data untuk meninjau aspek filosofis dan yuridis dan studi lapangan untuk menggali informasi dari KSSPS di Wilayah Jawa Timur sebagai data untuk menggali aspek sosiologis dari penerapan Peraturan Menteri Nomor 11 tahun 2017. Adapun Hasil dari penelitian ini adalah; keberlakuan hukum dari Peraturan Menteri KUKM RI Nomor: 11/PER/M.KUKM/XII/2017 di pandang dari filosofis ternyata tidak selaras dengan cita hukum koperasi di Indonesia, sedangkan dari sisi yuridis ditemukan kekosongan hukum, dari dimensi sosiologis belum bisa berjalan dengan sempurna disebabkan dari faktor sosialisasi pemangku kebijakan yang kurang optimal.

Keywords: legal validity; sharia cooperatives; KSPPS; BMT; operational permits

\section{Introduction}

The law concerning Microfinance Institutions (MFI) of 2013 significantly affects the arrangements and operations of non-bank financial institutions, particularly Baitul Maal Wa Tamwil (BMT) and Savings and Loan Cooperatives and Sharia Financing (KSPPS). Earlier, both were under the auspices of the Ministry of Cooperatives and Small and Medium Enterprises (SMEs). But, after the Law enactment, BMT shifts under the auspices of the Financial Services Authority $(\mathrm{OJK})$ and KSPPS is still under the the Ministry of Cooperatives and SMEs.

According to the latest regulations (OJK Regulation Number:12 / POJK.05/2014, n.d.), BMT is a Microfinance Institution incorporated as a limited liability company that carries out its business activities in the form of collecting and distributing funds and managing infaq, alms, zakat, infaq, and waqf of the community at large. Its operational permit is issued by the OJK to which it carries out its responsibilities.

Meanwhile, based on the Regulation of Minister of Cooperatives and SMEs Number: 11/PER/M.KUKM/XII/2017, KSPPS is a financial institution with a cooperative operational permit whose business activities are savings, loans, and financing based on sharia principles, including managing infaq, alms, zakat, infaq, and waqf. In addition, all financial institution with KSSP business license is obliged to display a symbol or logo 
of the cooperative movement on the nameplate at the head and service network office (Regulation of Minister of Cooperatives and SMEs, 2017). However, what happens in the field is that KSPPS in East Java in their operations still use the BMT brand. In this case, there are 1121 KSSPS in East Java (Data Koperasi, 2019), and more than 10 KSSPS still use the BMT brand (Google.inc, 2020), such as UGT Sidogiri (BMT Sidogiri, 2020) which in principle has a KSPPS permit but in branding still uses name BMT to maintain the market due to its location in pesantren (BMT UGT Sido Giri, no date). BMT Mandiri Berkah Sejahtera Syariah with its KPPS permit also uses the BMT because people in Jiwan Madiun assume KSPPS is not sharia (Sugeng, no date), and so does KSPPS Hasanah Ponorogo. In addition, its human resources are not qualified to fulfill OJK requirements for BMT operational permit (Sasono, 2019). Other KSPPS such as BMT Surya Mandiri (Fuadi, 2019), BMT Surya Abadi Jenangan (Putro, 2019), BMT surya kencana Balong, BMT Al-Islam Tulungagung (Ijin Operasional, 2019), and BMT Maslahah Surabaya (Ijin Operasional, 2019) have similar reasons. So far, it can be concluded that KSPPS in East Java prefer to use BMT brand even with KSPPS operational permit.

There discrepancy between the regulation and its application happens by reason. KSPPSs continue to use BMT brand to maintain the existence of Islamic financial institutions, but they have no qualified human resource to fulfill OJK requirements for BMT permits. Whereas, If KSPPS still maintain BMT brand, problems will emerge, in the form of disputes between the two parties and public confussion regarding false information.

Viewed from legal theory, the rule functions as a mean to achieve justice, and benefit on philosophical, juridical and sociological dimensions. The law needs to be functioned to achieve this goal, as a driver of development where it can bring society to a more advanced direction (Soeroso, 2016;36; see also Daryanto \& Karim, n.d.;42).

To see the function and purpose of the law, practically it can be related to the legal validity theory with its various dimensions. First, social dimension closely related to empirical aspects, namely the benefit purpose and dispute resolution function. Second, philosophical dimension with its long term goal to change and engineer society. Third, juridical dimension that makes the law a force which is in accordance with the long-term function of law to maintain social order. 
The existence of Law concerning sharia cooperative, BMT and KSPPS has been studied by several researchers including: Monteagudo \& Martínez (2020) analyzing cooperative institutions from various countries, Muhtarom (2016) discussing the legal reformulation of Islamic financial institutions, Sofiana (2014) discussing the legal norms of cooperatives within the framework of the existing legal system in Indonesia, and Nourmadewi discussing the existence of BMT regulations (Law Faculty of UNIBA, 2017). Different from previous research, this study examines the validity of the KSPPS regulatory law from the philosophical, juridical and sociological dimensions.

This research aimed at describing the validity of Ministerial Regulation Number 11/ PER/M.KUKM/XII/2017 in KSPPS(s) of East Java Region based on the philosophical, juridical, sociological dimensions.

\section{Methodology}

This was a qualitative study with sociological, juridical, philosophical approach. Data collection techniques were divided into two, namely literature study to explore legal documents as data to review philosophical and juridical aspects and field studies to explore information from KSSPS in East Java as data to explore sociological validity of Ministerial Regulation No. 11 of 2017. Literature study was done by looking at the legal facts related to regulations regarding BMT, Regulation of Minister of Cooperatives and SMEs, and OJK Regulation as the norms. These norms were then reviewed for their suitability in the practical realm, meaning that syllogistic reasoning was applied in this process. Meanwhile, field studies were carried out by digging up data in the field. The methods used were observation and interviews. In the field research, not all KSSPSs were interviewed, the researchers interviewed only 40 of them. This study used deductive reasoning to review two aspects, namely the philosophical aspect and the juridical aspect of the KSSPS arrangement in Indonesia. While inductive reasoning was used to find sociological problems arising in the field.

\section{Legal validity}

Law is considered good when formed based on several aspects: sociological, juridical, philosophical and even political and administrative aspects. Those three are important in measuring the strength of its validity, (Asshiddiqie, 2006: 85; see also Mertokusumo, 
2005:67). The validity of positive law is more identical with the achievement of its purposes. Radburch stated that the purpose of law is the achievement of a rule related to justice, certainty and usefulness. Semantically, legal validity can be interpreted in empirical, normative and evaluative forms (J.J. H. Bruggink translated by Sidharta, 2011;138). Therefore, it is understood that there is a relationship between the purpose of law and its validity. Here is the Bruggink's behavior scheme:

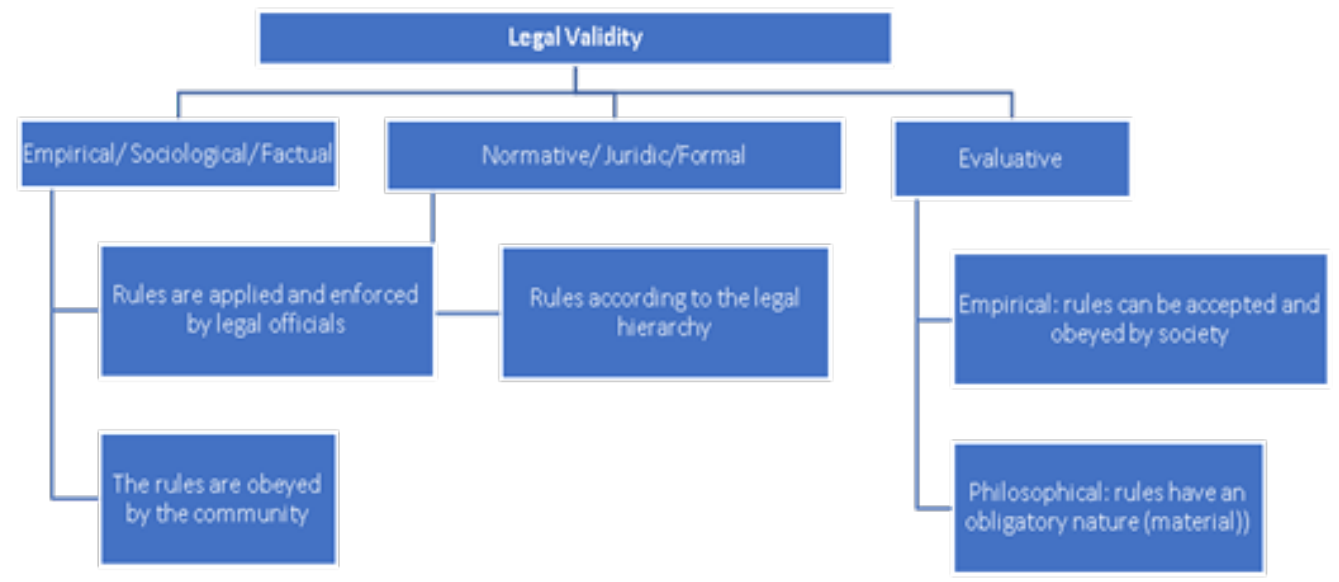

\section{Sociological validity (soziologischegeltung)}

It is a validity that has an empirical tendency with several choices of criteria: recognition and reception theory or legal facticity criteria (Přibáň, 2017;15).

Sociologically, it is determined by non-juridical factors viewed from sociological (empirical) approach (Wilamarta \& Barus, 2012;89), it is closely related to the empirical aspects of the benefit purpose and dispute resolution function (Darmodiharjo \& Shidarta, 2008;53). That is the background of the term: law as a product of social interaction (Barus, 2013;78). This means that in this soziologischegeltung legal rules are applied and enforced by legal officials in the community (maschtstheorie) and these rules can be accepted, recognized and applied by the community (anerkennungstheorie) (Mulyanto, 2016;23), meaning that the law is effective when the community consider it as representation of normally running justice and is not just a normative symptom or a social phenomenon. Thus the law must be 
Ijtihad: Jurnal Wacana Hukum Islam dan Kemanusiaan, Volume 21, No. 1, Juni 2021: 59-78

able to keep up with changing conditions in the community situation to avoid legal vacuum (Ehrlich, 2017;8). Therefore, the legal position of this dimension is law as a public tool which always follows the development of its users.

\section{Juridical validity (juridisgeltung)}

It is a validity based on legal norms as legal dogmatic that have a juridical technical nature. In this dimension, an effective law has following criteria: (i) determined as a legal norm based on a superior law (ii) able to bind (iii) determined as a legal norm based on the formation of law (iv) its validity is determined by the authorized institution (Dayanto \& Karim, 2015;42).

There are several considerations in positive law format, namely (i) remembering; containimg the juridical and administrative basis for the law formulation, (ii) considering; containing considerations regarding the law formulation, (iii) Regarding; containing the attention of the law formulation. In the law formulation in Indonesia, the first and second considerations are absolute, while the third is facultative (Law Faculty, Universitas Hasanuddin, 2015;29).

The juridical validity makes the law a force (Marbun, 2014;63) which is in accordance with the long-term legal function positioning law as the guardian of social order (Shidarta, 2014;23). With this, the juridical dimension wants to realize legal certainty and therefore the law enforceability is called juridical validity, and the law is considered to be effective juridically if the formal requirements for the formation of rules or laws are met (Mulyanto, 2016;16). The juridical dimension wants to realize legal certainty, by making the law a "master" and the community as 'a servant' (Wilamarta \& Barus, 2012;23).

\section{Philosophical validity (filosofischegeltung)}

It is a validity based on the philosophical values set by the Indonesian state, namely Pancasila as staatsfundamentalnorm, because the philosophical foundation is nothing but ideal norms, therefore the existing philosophical values should not be ignored (Taniredja, Afandi, \& Faridli, 2012;102).

Its validity philosophically has an ideal nature because this dimension wants to change and engineer society (Darmodiharjo \& Shidarta, 2008;105). The law is effective based on its philosophy if it can run in accordance with the ideals of the law (Mulyanto, 2016;28). 
Law, in a philosophical approach, has the usefulness values principle that can realize truth and justice regardless to sociological or juridical processes. If the law does not reflect the values contained in the purpose of its establishment, it automatically has no philosophical legitimacy. This philosophical dimension is a consideration between juridical and sociological dimension, and its scale will show the law usefulness in society (Wilamarta \& Barus, 2012;47).

\section{The sosiological validity of KSPPS operational permits and brandings in East Java}

The sociological validity of the Ministerial Regulation Number: 11/PER/M.KUKM/ XII/2017 in the East Java KSPPS can be measured using several indicators: 1) legal socialization by the government, 2) legal culture community, 3) enforcement of legal sanctions.

The legal socialization in this study refers to the term legal counseling, interpreted as an activity to disseminate information and provide an understanding of the prevailing norms, laws and regulations to establish the community legal awareness (Ministry of Law and Human Right RI, 2007). Legal awareness is a value that lives in society, in the form of understanding and obedience to legal rules. The output of legal socialization is legal awareness. The forms of legal counseling that are generally carried out by the government are the use of communication media and legal socialization both electronically and nonelectronically (Legal Socialization, 2016). Based on this assumption, the following analysis are taken:

First, from legal socialization aspect, researchers found several models carried out by the government, namely website publication, training and socialization. Regarding publications, there are 2 websites used for socialization, owned by the Ministry of Law and Human Rights. Interestingly, Ministerial Regulation Number: 11/PER/M.KUKM/ XII/2017 was not found on the website of the East Java Department of Cooperatives (Regulation, 2019). It shows that the legal socialization using publication stopped until central government. Furthermore, based on the results of interviews with 40 KSPPS in East Java, 26 KSPPS including Hasanah (Sasono, 2019), BMD Syariah (Koperasi Syariah, 2019), Assalam pacitan (Koperasi Syariah, 2019), Nur Rohman (Koperasi Syariah, 2019), Ngabar (Koperasi Syariah, 2019), Surya Kencana Balong (Koperasi Syariah, 2019), Arrido 
Ijtihad: Jurnal Wacana Hukum Islam dan Kemanusiaan, Volume 21, No. 1, Juni 2021: 59-78

Trenggalek (Koperasi Syariah, 2019), Peta Tulungagung (Koperasi Syariah, 2019), Melati Mojokerto (Koperasi Syariah, 2019), Nusantara Mojo Pahit (Koperasi Syariah, 2019), MBS Madiun (Sugeng, no date), Surya Mandiri (Fuadi, 2019), Al-Islam Tulungagung (Ijin Operasional, 2019), Maslahah (“Operational Permit,” 2019), Amanatul Ummah (Koperasi Syariah, 2019), Muamalah syariah (Koperasi Syariah, 2019), Tunas arta mandiri (Koperasi Syariah, 2019), Lantaburcukir (Mun'im, 2019), Al-Wahidah (Wahyunadi et al., 2017) Gresik, BMT NU Sumber sari (Isna, 2019), BIM Babad (Jiyanto, 2019), Bina Umat Sejahtera (Koperasi Syariah, 2019), Muslimat Putat (Koperasi Syariah, 2019), Ummul Mukminin Pamekasan (Koperasi Syariah, 2019), Sibisa Al-Khairat pamekasan (Koperasi Syariah, 2019), Al-Fitrah Surabaya (Sofyan, 2019) tend to visit the Ministry of Cooperatives and SMEs website. Therefore, it can be assumed that publications made by the government should have been accessed by KSPPS in East Java. From the interview regarding the materials accessed, it turned out to be dominated by operational, monitoring and reporting aspects. While materials regarding legal products are rarely accessed. This shows that although socialization has been carried out through website, KSPPS still get difficulties in understanding and accessing the publication of the regulation. This fact indicates the need of legal socialization.

Interviews regarding socialization and training resulted some information. The interviewees including KSPPS Nuri (Koperasi Syariah, 2019), KSPPS Hasanah (Sasono, 2019), KSPPS: Sumber Harapan Maju (Koperasi Syariah, 2019), Lantaburcukir (Mun'im, 2019), Al-Wahidah (Wahyunadi et al., 2017) Gresik, BMT NU Sumber sari (Isna, 2019), BIM Babad (Koperasi Syariah, 2019), Bina Umat Sejahtera (Koperasi Syariah, 2019) and several others answered that they had participated in socialization of new regulations. Even, some KPPS including Nur Rohman (Koperasi Syariah, 2019), Ngabar (Koperasi Syariah, 2019), Surya Kencana Balong (Koperasi Syariah, 2019), Arrido Trenggalek (Koperasi Syariah, 2019), Peta Tulungagung (Koperasi Syariah, 2019), Melati Mojokerto (Koperasi Syariah, 2019), Nusantara Mojo Pahit (Koperasi Syariah, 2019), Hasanah (Sasono, 2019), BMD Syariah (Koperasi Syariah, 2019), Assalam pacitan (Koperasi Syariah, 2019) participated in socialization of regulations starting from KSPPS establishment until the socialization regarding Coperative Law draft. Based on the answers, it can be seen that the government, 
especially the East Java Cooperative Department, has actually conduct socialization related to the coopeeatives legal aspects.

The second indicator is the legal culture aspect. It is defined as the attitude of a person, human being, and organization towards the law. This attitude can be in the form of beliefs, thoughts and expectations or values (Friedma, 2001;74).

In this term, it was found that KSPPS in East Java have actually implemented a good legal culture, proved by the existence of internal regulations in the majority of cooperatives. They have also implemented sanctions against employees who violate them, in fact they also apply other cultures, namely religious practices such as routine tausiyah and recitation, as KSPPS reflection and characteristic. In addition, the majority of KSPPS also have Sharia Supervisory Board (DPS) such as KSPPS Hasanah (Sasono, 2019), BMD Syariah (Koperasi Syariah, 2019), Assalam pacitan (Koperasi Syariah, 2019), Nur Rohman (Koperasi Syariah, 2019), Ngabar (Koperasi Syariah, 2019), Surya Kencana Balong (Koperasi Syariah, 2019), Arrido Trenggalek (Koperasi Syariah, 2019), Peta Tulungagung (Koperasi Syariah, 2019), Melati Mojokerto (Koperasi Syariah, 2019), Nusantara Mojo Pahit (Koperasi Syariah, 2019), MBS Madiun (Sugeng, no date), Surya Mandiri (Fuadi, 2019), Al-Islam Tulungagung (Ijin Operasional, 2019), Maslahah (Ijin Operasional, 2019), Amanatul Ummah (Koperasi Syariah, 2019), Muamalah syariah (Koperasi Syariah, 2019), Tunas arta mandiri (Koperasi Syariah, 2019), Lantaburcukir (Mun'im, 2019), Al-Wahidah (Wahyunadi et al., 2017) Gresik, BMT NU Sumber sari (Isna, 2019), BIM Babad (Koperasi Syariah, 2019), Bina Umat Sejahtera (Koperasi Syariah, 2019), Muslimat Putat (Koperasi Syariah, 2019), Ummul mukminin pamekasan (Koperasi Syariah, 2019), Sibisa Al-Khairat pamekasan (Koperasi Syariah, 2019), Al-Fitrah Surabaya (Koperasi Syariah, 2019).

Another thing also used as an indicator in the legal culture is related to cooperative associations and the prevailing code of ethics. Regarding this, 50\% of KSPPS including Tunas Arta Mandiri (Koperasi Syariah, 2019), Lantaburcukir (Mun'im, 2019), Al-Wahidah (Wahyunadi et al., 2017) Gresik, BMT NU Sumber sari (Isna, 2019), BIM Babad (Koperasi Syariah, 2019), Bina Umat Sejahtera (Koperasi Syariah, 2019), Muslimat Putat (Koperasi Syariah, 2019), Ummul Mukminin Pamekasan (Koperasi Syariah, 2019), Sibisa Al-Khairat Pamekasan (Koperasi Syariah, 2019), Al-Fitrah Surabaya (Koperasi Syariah, 2019), KSPPS 
Ijtihad: Jurnal Wacana Hukum Islam dan Kemanusiaan, Volume 21, No. 1, Juni 2021: 59-78

Nuri (Koperasi Syariah, 2019), KSPPS Hasanah (Sasono, 2019), KSPPS Sumber Harapan Maju (Koperasi Syariah, 2019), Lantaburcukir (Mun'im, 2019), Al-Wahidah (Wahyunadi et al., 2017) Gresik, BMT NU Sumber Sari (Isna, 2019), BIM Babad (Koperasi Syariah, 2019), Bina Umat Sejahtera (Koperasi Syariah, 2019) answered that they had participated in sharia cooperative organizations. However, of the 50\% KSPPS, only half are aware of the existence of a cooperative code of ethics. This means that the overall application of cooperative legal culture in East Java is still relatively weak from the external aspect. Assessment of legal compliance in relation to the participation of cooperatives with this organization is based on the theory of R. Bierstedt. Soekanto (2001: 28) said that the means to identify a person or group is their compliance level with the rule of law, which in this case, there is code of ethics in the association and the regulation to comply all types of rules in the cooperative field. As the KSPPS effort to maintain their existence, they have to always obey all existing rules.

Regarding cooperative regulations, from the interviews with 40 the mentioned KSPPS, they generally answered that the existing regulations were appropriate and should be obeyed. However, the answers were contradictory to the fact, found from interviews and online media support in the form of a website, that most of them still use BMT brand without including the phrase "KSPPS" (Google.inc, 2020; MAP BMT Karesidenan Madiun, 2019; BMT Sidogiri, 2020; Ijin Operasioanal 2019; Koperasi Syariah 2019; Koperasi Syariah, 2019; Sugeng, no date).

The last benchmark in assessing the sociological validity of regulation is related to sanctions. According to Black's Law Dictionary, sanctions are: "A penalty or coercive measure that results from failure to comply with a law, rule, or order (a sanction for discovery abuse)"

Sanctions are divided into 3 types: criminal, civil and administrative sanctions. Criminal sanction is often referred to as punishments. While civil sanction is actually related to the judge's decision, only it is again divided into 3 forms: condemtanoir, decralatoir, and constitutive decisions (Wahid, 2020). The last is administrative sanctions and generally in the form of imposition of fines, freezing, temporary termination of services and other administrative actions. 
Regarding sanctions, KSPPS in general including Sumber Harapan maju (Koperasi Syariah, 2019), Al Islam (Damanuri, 2019), (Sasono, 2019), Harapan (Koperasi Syariah, 2019) and others said that they knew about sanctions for cooperatives in case of violations, and even the toughest sanctions were the dissolution and revocation of permits.

The optimal implementation of legal culture by cooperatives as well as their fear of sanctions show that KSPPS seems to be deliberately ignoring the regulations regarding the necessity to change the BMT brand to KSPPS. Hence, the researchers conclude that the indifferent behavior that lies behind the Ministerial Regulation Number 11/PER/M.KUKM/XII/2017 paticularly concerning the use of KSPPS name in the logo and nameplate is caused by non optimal legal socialization, not the weakness of community legal culture and sanctions.

\section{Juridical validity of KSPPS operational permits and brandings in East Java}

The approach used by researchers in unraveling the validity of the Regulation Number 11/PER/M.KUKM/XII/2017 concerning KPPS operational permits and branding in the East Java region based on the juridical dimension, begining with historical approach and continues with regulatory material. The historical approach tries to see a legal product from the aspect of chronology or periodization and also the surrounding historical factc. This historical fact is considered to be the background for the existence of regulations and at the same time can also be used to assess whether a regulation has really developed in accordance with the development of society (Nasution, 2008: 52).

From the historical aspect of the preparation, it is known that this rule invalidates all provisions related to sharia cooperatives in the form of the previous regulation, namely: Article 36 Paragraph 7 of Ministerial Regulation Number Number: 91/Kep/M.KUKM/ IX/2004 and 35.2/ PER/M.KUKM/X/2007.

In tracing the regulation history, it is also found that until now there is no Law as legal basis for sharia cooperatives in Indonesia. The Law no. 25 Th. 1992 concerning Cooperatives which currently prevails also does not include any article that implicitly or explicitly mentions the phrase "sharia cooperatives", even though historically sharia cooperatives have emerged since July 4, 1984 under the name cooperative services expertise. Although it appeared in Law no. 12 of 2017 concerning Cooperatives, this regulation was 
ljtihad: Jurnal Wacana Hukum Islam dan Kemanusiaan, Volume 21, No. 1, Juni 2021: 59-78

later declared null and void by the Constitutional Court and the cooperative rules returned to the previous Law, namely Law no. 25 of 1992.

The fact that sharia cooperatives are increasingly developing as a typical sharia microfinance institution in the form of Baitul Mal Wa Tamwil (BMT) pressures the government to immediately close the legal vacuum, this is what lies behind the Regulation Number: 11/ PER/M.KUKM/XII/2017.

The second indicator is the formal and material basis of the statutory regulations. The formal and material basis is none other than to answer the question whether this regulation has been made legally.

The purpose of this formal and material basis is the constitutional formal and material basis which are the basis in the process of forming the Regulation Number: 11/PER/M. KUKM/XII/2017. The formal foundation itself is the basis that can be used as procedural legitimacy for the formation of a statutory regulation. Usually this formal basis is listed in the "remembering" section of a regulation. Whereas material basis is the basis that provides legitimacy that a statutory regulation is an elaboration of the 1945 Constitution and is generally stated after the phrase "remembering" in a statutory regulation. This formal basis is then further elaborated in brief in the form of articles or norms included after the phrase "considering" (Aziz, 2009;61).

The researchers assume that the Regulation has formal and material weakness for not accomodating sharia cooperatives. The considerations in this regulation are as follows:

1. Whereas, in order to increase access to financing for the community to carry out productive businesses, it is necessary to develop professional and competitive sharia savings and loan and financing businesses;

2. Whereas, for the effectiveness of implementing the development of sharia savings and loan businesses and financing by cooperatives, the Regulation of the Minister of Cooperatives and Small and Medium Enterprises Number 16/PER/M.KUKM/IX/2015 concerning the Implementation of Sharia Savings and Loans and Financing Business Activities by Cooperatives needs to be improved.

3. Whereas, based on the considerations as referred to in letters a and b, it is necessary to stipulate a Regulation of the Minister of Cooperatives and Small and Medium Enterprises concerning the Implementation of Sharia Savings and Loans and Financing Business Activities by Cooperatives (Regulation of Minister of Cooperatives and SMEs, 2017) 
It can be seen from these considerations that the formal basis of the regulation is to increase access to financing productive businesses. Furthermore, the material basis in the Law is based on the assumption that the Regulation is out to date and improvement is needed. The study found no anomalies in the regulation's formal and material basis.

However, after further exploration, it is found that there are 27 Laws and Regulations related to cooperatives both substantially and procedurally, and 20 of them are used as formal and material basis. In this study, they were then divided and classified into substantial and procedural elements as follows:

Regulations relating to procedural and formal elements:

Table 1. Formal Elements in Ministerial Regulation

\begin{tabular}{|c|c|c|}
\hline No & Regulations Numbers & Types \\
\hline 1 & $\begin{array}{l}\text { Presidential Regulation Number } 165 \text { of } \\
2014\end{array}$ & $\begin{array}{l}\text { Concerning Structuring the Duties } \\
\text { and Functions of the "Kabinet Kerja" }\end{array}$ \\
\hline 2 & Presidential Regulation Number 7 of 2015 & $\begin{array}{l}\text { Concerning State Ministry } \\
\text { Organization }\end{array}$ \\
\hline 3 & $\begin{array}{l}\text { Presidential Regulation Number } 62 \text { of } \\
2015\end{array}$ & $\begin{array}{l}\text { Concerning the Ministry of } \\
\text { Cooperatives, and SMEs }\end{array}$ \\
\hline 4 & $\begin{array}{l}\text { Regulation of Minister of Cooperatives } \\
\text { and SMEs Number 15/PER/M.KUKM/ } \\
\text { XII/2016 }\end{array}$ & $\begin{array}{l}\text { Concerning the Job Description of } \\
\text { Structural Officials in the Ministry of } \\
\text { Cooperatives and SMEs }\end{array}$ \\
\hline
\end{tabular}

From the formal aspect, there were no significant problems related to the rights and authorities of the minister as the authorized institution to issue regulations concerning cooperatives in general, both for sharia and conventional cooperatives.

Regulations relating to substantial formal and material elements 
ljtihad: Jurnal Wacana Hukum Islam dan Kemanusiaan, Volume 21, No. 1, Juni 2021: 59-78

Table 2. Material Elements of Ministerial Regulations

\begin{tabular}{|c|c|c|}
\hline No & Regulations Number & Types \\
\hline 1 & Law Number 25 of 1992 & Concerning Cooperative \\
\hline 2 & Law Number 41 of 2004 & Concerning Waqf \\
\hline 3 & Law Number 23 of 2011 & Concerning Zakat Management \\
\hline 4 & Law Number 1 Of 2013 & Concerning Microfinance Institutions \\
\hline 5 & Law Number 23 of 2014 & Concerning Local Government \\
\hline 6 & $\begin{array}{l}\text { Government Regulation Number } 4 \text { of } \\
1994\end{array}$ & $\begin{array}{l}\text { Concerning Requirements and } \\
\text { Procedures for Ratification of } \\
\text { the Deed of Establishment and } \\
\text { Amendment to the Articles of } \\
\text { Cooperatives Association }\end{array}$ \\
\hline 7 & $\begin{array}{l}\text { Government Regulation Number } 17 \text { of } \\
1994\end{array}$ & $\begin{array}{l}\text { Concerning the Dissolution of } \\
\text { Cooperatives by the Government }\end{array}$ \\
\hline 8 & $\begin{array}{l}\text { Government Regulation Number } 9 \text { of } \\
1995\end{array}$ & $\begin{array}{l}\text { Concerning the Implementation of } \\
\text { Savings and Loans Business Activities } \\
\text { by Cooperatives }\end{array}$ \\
\hline 9 & $\begin{array}{l}\text { Government Regulation Number } 33 \text { of } \\
1998\end{array}$ & $\begin{array}{l}\text { Concerning Cooperative Equity } \\
\text { Participation }\end{array}$ \\
\hline 10 & $\begin{array}{l}\text { Government Regulation Number } 42 \text { of } \\
2006\end{array}$ & $\begin{array}{l}\text { Concerning the Implementation of } \\
\text { Law Number } 41 \text { of } 2004 \text { concerning } \\
\text { Waqf }\end{array}$ \\
\hline 11 & $\begin{array}{l}\text { Government Regulation Number } 14 \text { of } \\
2014\end{array}$ & $\begin{array}{l}\text { Concerning the Implementation of } \\
\text { Law Number } 23 \text { of } 2011 \text { concerning } \\
\text { Zakat Management }\end{array}$ \\
\hline 12 & $\begin{array}{l}\text { Regulation of Minister of Cooperatives } \\
\text { and SMEs Number 10/PER/M.KUKM/ } \\
\text { IX/2015 }\end{array}$ & Concerning Cooperative Institution \\
\hline 13 & $\begin{array}{l}\text { Regulation of Minister of Cooperatives } \\
\text { and SMEs Number 11/PER/M.KUKM/ } \\
\text { IX/2015 }\end{array}$ & $\begin{array}{l}\text { Concerning the Implementation } \\
\text { Guidelines for Participating Capital } \\
\text { Fertilization in Cooperatives }\end{array}$ \\
\hline 14 & $\begin{array}{l}\text { Regulation of Minister of Cooperatives } \\
\text { and SMEs Number 15/PER/M.KUKM/ } \\
\text { IX/2015 as revised by Regulation of } \\
\text { Minister of Cooperatives and SMEs } \\
\text { Number 02/PER/M.KUKM/II/2017 }\end{array}$ & $\begin{array}{l}\text { Concerning Savings and Loans } \\
\text { Business by Cooperatives }\end{array}$ \\
\hline
\end{tabular}


Operational permits and brandings of savings and loan cooperatives...(Anjar Kususiyanah, et.al)

\begin{tabular}{cll}
\hline No & \multicolumn{1}{c}{ Regulations Number } & \multicolumn{1}{c}{ Types } \\
\hline 15 & $\begin{array}{l}\text { Regulation of Minister of Cooperatives } \\
\text { and SMEs Number 17/PER/M.KUKM/ }\end{array}$ & Concerning Cooperative Supervision \\
& IX/2015 & \\
16 & $\begin{array}{l}\text { Decree of the Indonesian Ulama Council } \\
\text { Number Kep-754/MUI/II/1999 }\end{array}$ & $\begin{array}{l}\text { Concerning the Establishment of } \\
\text { the National Sharia Council of the }\end{array}$ \\
& & Indonesian Ulama Council. \\
\hline
\end{tabular}

Furthermore, from the material aspect, several irrelevant things were found, namely the legal basis in the form of Law no. 25 of 1992 which actually does not contain provisions concerning sharia cooperatives. IT only regulates the Savings and Loans Cooperatives which practically apply the conventional system. However, that does not mean that the provisions do not cover sharia cooperatives. In more detail in Article 44 of Law no. 25 of 1992 is explained as that cooperatives can collect funds and distribute them through savings and loan business activities from and for: a) members of the cooperative concerned; b) Other cooperatives and/or their members. Savings and loans business activities can be carried out as one or the only cooperatives business activities. The implementation of savings and loan business activities by Cooperatives is further regulated by Government Regulation.

This general provision shows that the Law can be used as a material basis for drafting Ministerial regulations. The phrase "further regulated by Government Regulation" also shows an indication that there has been a legal gap/vacancy in the form of a Government Regulation. This is because the existing regulations are only in the form of a Ministerial Regulation.

\section{Philosophical validity of KSPPS operational permits and brandings in East Java}

Because this philosophical dimension positions as a balance between juridical legal certainty and sociological legal justice, the measure of philosophical validity in the Ministerial Regulation Number: 11/PER/M.KUKM/XII/2017 concerning KSPPS operational permits and branding in East Java, the researchers used the juridical and sociological approach which in the end coud prove the validity of legal ideals.

The historical facts described in the juridical dimension show that the government has not fully accommodated the community legal ideals. The government is too focused on the term 
Ijtihad: Jurnal Wacana Hukum Islam dan Kemanusiaan, Volume 21, No. 1, Juni 2021: 59-78

cooperatives as the pillars of the economy, cooperatives only emerge from the Indonesian tradition of gotong royong (mutual cooperation). It is not a problem, but considering the fact that the Indonesian people from the beginning have implemented a sharia system in cooperatives, it needs to be accommodated, especially in the form of a Law.

That aspect shows that government's effort regarding the regulation of sharia cooperatives has not truly reflected community legal ideals that has developed sharia cooperative since independence. Besides, these provisions do not fully reflect operational activities of sharia cooperatives, especially BMT. Therefore, the Government as authorized party has to formulate a Law concerning BMT.

In this case then the explanation regarding the social background at the time of enactment of this regulation becomes necessary to be disclosed further. Based on the results of fact-finding conducted by researchers, several things were found, namely:

First, BMT is a social intermediaryor Microfinance Institution that bridges among lowincome people who have not been served by bank financial services.

Second, the name BMT is a characteristic that emerged and developed in Indonesia. It is the only Microfinance Institution that is able to combine two important paradigms, namely the commercial paradigm (institutionalist) and social orientation (welfarist). Furthermore, the founding fathers still prefer to use the name BMT, they have used it from the beginning.

Finally, the name BMT itself is not only a branding for the institution concerned, it is also a branding for the State of Indonesia.

In this regard, the Ministerial Regulation Number: 11/PER/M.KUKM/XII/2017 which requires a change in the name of BMT to KSPPS is considered not in accordance with the legal ideals of the BMT founders. Besides, it also reduces the value of BMT. as a characteristic of Islamic microfinance institutions in Indonesia. Moreover, the name KSPPS also eliminates the BMT branding in Indonesia.

However, the regulation is not coercive, there are options for the legal entity as explained in the previous discussion, namely:

"The Governor of Bank Indonesia with the Minister of Cooperatives and MSMEs, the Minister of Finance and the Minister of Home Affairs made a joint decree Number 11/43a/KEP.GBI/2009/2009 Number 900-639a of 2009, Number 01/ SKB/M.KUKM/IX/ 2009 and Number 351.1/KMK/010/2009 which contents allow 
microfinance institutions to rely on the rules of BPRS or BUMDes or cooperatives in accordance with their wishes. If the BMT chooses to become a BPRS as a legal entity, it must comply with banking regulations, as well as when choosing to become a BUMDes legal entity, it must comply with the BUMDes regulations. If BMT chooses to become a cooperative legal entity, it must comply with the cooperative law by changing its name to the Sharia Financial Services Cooperative (KJKS)".

Beside the option, the name of BMT is missing. BMT branding is no longer accommodated in several existing regulations. Based on this, the researchers conclude that eliminating the name BMT means eliminating the existence and characteristic of Islamic microfinance institutions in Indonesia, and is not in accordance with the community legal ideals. This is in line with National Sharia Finance Committee (KNKS) research with its recommendation:

"It is necessary to mention a name that can represent all Sharia Microfinance Institutions and without connecting with the terms as in Law no. 25 of 1992 and Law no. 1 of 2013 and its related provisions. And referring to the early growth of Sharia Microfinance Institutions in the country, where the founding figures have given the concept, movement, and the name Baitul Maal WaTamwil abbreviated as BMT."

The statement above shows that sociologically this regulation cannot yet apply and is not in accordance with the current growth of BMT.

Regarding juridical validity, historically the government has not been responsive to the sharia cooperatives development. The regulations related to sharia cooperatives are not in accordance with legal ideals, because sharia cooperatives have developed since before the Law and Regulations concerning cooperatives. The Regulation Number: 11/PER/M. KUKM/XII/2017 materially contains a disability, due to the absence of Government Regulations as its material basis. Formally, the Ministerial Regulation has been formed and implemented in accordance with the procedure. The problem emerges because the contents of the regulation are not in accordance with the community legal ideals and the BMT stakeholders. Therefore, it is found that juridically there are still many weaknesses in the Regulation, so it has the potential for judicial review.

\section{Conclusion}

From the study, it could be concluded that the legal validity of the Minister of Cooperatives and SMEs Regulation Number: 11/PER/M.KUKM/XII/2017 is philosophically not in 
Ijtihad: Jurnal Wacana Hukum Islam dan Kemanusiaan, Volume 21, No. 1, Juni 2021: 59-78

accordance with legal ideals. Juridically, there is a legal vacuum in the KSSPS regulation in Indonesia. Furthermore, from the sociological dimension, it has not been able to run perfectly due to non-optimal socialization by policy makers.

The philosophical, juridical and sociological aspects of the Ministerial Regulation are weak, causing cooperatives, although not explicitly, to refuse. Simply, they are in the 4th level of Hoefnageles' Legal Compliance Categorization, that these KSSPS are like people who do not obey the law and values of the authority, but agree with them.

The research findings related to the position of KSSPS in Indonesia, which so far do not have a legal basis in the form of Law, can be used as a solid basis for conducting further study on the legal position of KSSPS in Indonesia.

\section{References}

Asshiddiqie, J. (2006) Perihal Undang-Undang. Jakarta: Konstitusi Press.

Aziz, M. (2009) 'Landasan Formil dan Materiil Konstitusional Peraturan PerundangUndangan', Jurnal Legislasi Indonesia.

Barus, Z. (2013) 'Analisis Filosofis Tentang Peta Konseptual Penelitian Hukum Normatif dan Penelitian Hukum Sosiologis', Jurnal Dinamika Hukum.

BMT Sidogiri (2020) Website BMT Sidogiri, https://bmtugtnusantara.co.id/home.

BMT UGT Sido Giri (no date) BMT UGT Sido Giri.

Darmodiharjo, D. and Shidarta (2008) Pokok-Pokok Filsafat Hukum ; Apa dan Bagaimana Filsafat Hukum Indonesia. Jakarta: Gramedia Pustaka Utama.

Daryanto and Karim, A. (no date) Peraturan Daerah Responsif Fondasi Teoritik Dan Pedoman Pementukannya,.

Data Koperasi (2019) Kementerian Koperasi dan Usaha Kecil dan Menengah Republik Indonesia.

Dayanto and Karim, A. (2015) Peraturan Daerah Responsif: : Fondasi Teoretik Dan Pedoman Pembentukannya. Yogyakarta: Budi Utama.

Ehrlich, E. (2017) Fundamental principles of the sociology of law, Fundamental Principles of the Sociology of Law. doi: 10.4324/9780203791127.

Fakultas Hukum UNIBA, N. (2017) 'Regulasi Keberadaan Baitul Maal Wat Tamwil (Bmt) 
Operational permits and brandings of savings and loan cooperatives...(Anjar Kususiyanah, et.al)

Dalam Sistem Perekonomian Di Indonesia', Serambi Hukum.

Friedma, L. M. (2001) Hukum Amerika Sebuah Pengantar. Jakarta: PT Tata Nusa.

Fuadi (2019) Ijin Operasional. Ponorogo.

Google.inc (2020) KSPPS Menggunakan Brand BMT di Jawa Timur, http:/ / maps.google. $\mathrm{com} /$.

Ijin Operasional (2019) BMT Maslahah.

Inmaculada, C. M. and Inmaculada, B.-M. (2020) 'Political Activism as Driver of Cooperative Sector', Voluntas. doi: 10.1007/s11266-020-00198-6.

Isna (2019) Koperasi Syariah. Surabaya.

J.J. H. Bruggink alih bahasa oleh B. Arief Sidharta (2011) Refleksi Tentang Hukum

Pengertian Pengertian Dasar Tentang Teori Hukum. Bandung: Citra Aditya Bakti.

KEMENKUMHAM RI (2007) Pola Penyuluhan Hukum. Indonesia.

Koperasi Syariah (2019) Nuri Jatim.

MAP BMT Karesidenan Madiun (2019) Google MAP.

Marbun, R. (2014) 'Grand Design Politik Hukum Pidana dan Sistem Hukum Pidana Indonesia Berdasarkan Pancasila dan Undang-Undang Dasar Negara Republik Indonesia 1945', PADJADJARAN Jurnal Ilmu Hukum (Journal of Law). doi: 10.22304/pjih.v1n3.a8.

Mertokusumo, S. (2005) Mengenal Hukum (suatu pengantar). edisi keli. Yogyakarta: Liberty. Muhtarom, M. (2016) 'REFORMULASI PERATURAN HUKUM LEMBAGA KEUANGAN MIKRO SYARIAH DI INDONESIA', Profetika: Jurnal Studi Islam. doi: $10.23917 /$ profetika.v17i01.2103.

Mulyanto, M. (2016) 'KEBERLAKUAN UU NO. 6 TAHUN 2014 TENTANG DESA DI BALI DALAM PERSPEKTIF SOSIOLOGI HUKUM', Mimbar Hukum - Fakultas Hukum Universitas Gadjah Mada. doi: 10.22146/jmh.15880.

Mun'im (2019) Koperasi Syariah. Jombang.

Nasution, J. (2008) Metode Penelitian Hukum. Bandung: Mandar Maju.

Pearaturan Otoritas Jasa Keuangan No:12 /POJK.05/2014 (no date).

Penyuluhan Hukum (2016).

PERMENKOP-UKM (2017) Pelaksanaan Kegiatan Usaha Simpan Pinjam dan Pembiayaan 
Ijtihad: Jurnal Wacana Hukum Islam dan Kemanusiaan, Volume 21, No. 1, Juni 2021: 59-78

Syariah Oleh Koperasi. Republik Indonesia.

Přibáň, J. (2017) 'A Sociology of Legal Distinctions: Introducing Contemporary Interpretations of Classic Socio-legal Concepts', Journal of Law and Society. doi: 10.1111/jols.12046.

Putro, W. A. (2019) Ijin Operasional. Ponorogo.

Regulasi (2019) Dinas Koperasi dan UKM Jawa Timur.

Sasono, T. (2019) Ijin Operasional. Ponorogo.

Shidarta, S. (2014) 'Fenomena Pedagang Kaki Lima dalam Sudut Pandang Kajian Filsafat Hukum dan Perlindungan Konsumen', Humaniora. doi: 10.21512/humaniora. v5i2.3213.

Soekanto, S. (2001) Kesadaran Hukum dan Kepatuhan Hukum. Jakarta: Rajawali.

Soeroso, R. (2016) Pengantar Ilmu Hukum. Jakarta: Sinar Grafika.

Sofiana, T. (2014) 'KONSTRUKSI NORMA HUKUM KOPERASI SYARIAH DALAM KERANGKA SISTEM HUKUM KOPERASI NASIONAL', JURNAL HUKUM ISLAM. doi: 10.28918/jhi.v1i1.535.

Sugeng (no date) BMT Mandiri Berkah Sejahtera, BMT Mandiri Berkah Sejahtera.

Taniredja, T., Afandi, M. and Faridli, E. M. (2012) 'The Appropriate Pancasila Education Contents to Implant Lofty Values for Indonesian Students', International Journal For Education Studies.

Universitas Hasanuddin. Fakultas Hukum, M. (2015) 'Hasanuddin law review.', Hasanuddin Law Review.

Wahid, S. H. (2020) Sanksi Hukum Pidana Perdata dan Administratif, Hukum Line.

Wahyunadi, Z. et al. (2017) 'Purba 113 - 131 MIX: Jurnal Ilmiah Manajemen, Volume VII, No. 1, Feb 2017', Jurnal Ilmiah Islam Futura.

Wilamarta, M. and Barus, Z. (2012) 'MANFAAT ANALISIS YURIDIS DAN SOSIOLOGIS YANG BERSIFAT KOMPLEMENTER DALAM PERJANJIAN KREDIT UNTUK MEMINIMALISIR RESIKO BANK SEBAGAI KREDITOR', Yustisia Jurnal Hukum. doi: 10.20961/yustisia.v1i2.10640. 